\title{
Comparing Ficus vogelii leaf extract and omeprazole as therapy and prophylaxis for aspirin-induced gastric ulcer in wistar rat.
}

\author{
Ezemagu UK*, Akunna GG, Egwu OA, Uzomba GC, Nwite KN \\ Alex-Ekwueme Federal University, Ndufu Alike Ikwo, Ebonyi State, Nigeria
}

\begin{abstract}
Background: A proper attention is required to prevent the gastric mucosa from injurious effect of aspirin.

Objective: We aim to examine the phytochemicals in aqueous extract of Ficus vogelii leaf (F.V.E), and compare their actions on aspirin-induced gastric ulcer with that of Omeprazole.

Materials and Methods: Thirty wistar rats (about 8 wks old and weight, $120 \mathrm{~g}$ each) were divided into 6 groups of five rats each. With the aid of oro-gastric cannula, the groups were administered a daily dose of Omeprazole and F.V.E as follows: group 1 (negative control)-2 $\mathrm{ml}$ of distilled water; group 2Omeprazole $20 \mathrm{mg} / \mathrm{kg}$ body weight (bwt) for 10 days, followed by aspirin $500 \mathrm{mg} / \mathrm{kg}$ bwt for $3 \mathrm{days}$; group 3-aspirin $500 \mathrm{mg} / \mathrm{kg}$ bwt for 3days, followed by F.V.E $600 \mathrm{mg} / \mathrm{kg}$ bwt for 10 days; group 4-aspirin $500 \mathrm{mg} / \mathrm{kg}$ bwt for 3 days, followed by Omeprazole $20 \mathrm{mg} / \mathrm{kg}$ bwt for 10 days; group 5-F.V.E $600 \mathrm{mg} / \mathrm{kg}$ bwt for 10 days, followed by aspirin $500 \mathrm{mg} / \mathrm{kg}$ bwt for 3 days; group 6 (positive control)-aspirin 500 $\mathrm{mg} / \mathrm{kg}$ bwt for 3 days. The rats were sacrificed and the stomach tissues were processed, stained with $H \&$ $E$ and PAS, and biochemically analyzed for NP-SH group concentration.

Results: F.V.E has high concentrations of saponins and flavonoids. Rats in group 1, 4 and 5 showed normal gastric mucosa. Group 2 and 6 showed gastric ulceration with significant increase in parietal cell count $(\mathbf{p}<0.01)$, and reduction in surface cell diameter and count. Group 3 showed evidence of regenerated mucosa. All groups except positive control had normal NP-SH group concentration.

Conclusion: The study proved that F.V.E could be used as both therapy and prophylaxis for aspirininduced gastric ulcer in wistar rat while omeprazole adequately served as a therapy for the ulcer.
\end{abstract}

Keywords: Gastric mucosa, Histopathology, Non-protein sulfhydryl group, Periodic acid Schiff, Prophylaxis, Steroids. Accepted on May 6, 2019

\section{Introduction}

The prevalence and severity of aspirin related gastrointestinal injury, requires efforts being directed at the prevention of such complication, since there are enormous health benefits of aspirin administration. Previous researchers have established widely accepted mechanism of action of aspirin in relation to gastric mucosa ulceration [1-3] and anti-inflammatory effects of Ficus vogelii leaf extract in some experimental animals $[4,5]$. Despite the fact that there are available proton pump inhibitors such as Omeprazole, targeting gastric ulceration therapy, potent prophylactic drugs for aspirin induced ulceration are required. Facts from this study may introduce new targets of pharmacologic agents to address the above proposal.

Consistently, copious literature [6-8] has established the gastroprotective or anti-ulcerative effects of different plant extracts. As such, botanical compounds with anti-ulcerative effect includes Flavonoids, Saponin, Tannins, Gums and Mucilages which have been isolated from plants such as Aloe vera [9], Ficus arnottiana [10], Magnifera indica and Moringa pterygosperma [11], Ficus exasperate [12], Aegles memolos and Ficus religiosa [13] and Ficus vogelii [4]. Notably, administration of crude extract of Ficus thonningii for 7 days led to a significant increase in the stomach mass, and mucosal layer thickness [14].

Interestingly, Ficus vogelii has wild ethno medical applications, and it serves as vegetable to prepare different types of dishes, among different tribes in Nigeria, which include the Ikwo Noyo clan people of Ebonyi State, and Obudu people of cross river state [4]. The leaf extract boost the haemoglobin level in children, and increases their body weight $[4,5]$. However, literature reveals lack of uniformity in the chemical and physical qualities of an herb [15-17].

Hence, the aim of this study was to ascertain the different concentrations of the basic phytochemicals in aqueous extract of Ficus vogelii leaf found at Ebonyi State, Nigeria. Furthermore, compare its prophylactic and therapeutic actions on aspirin induced gastric ulcer in Wistar rat with that of Omeprazole. 


\section{Material and Methods}

\section{Plant preparation and extraction}

Fresh leaves of Ficus vogelii were harvested from three different resident compounds in Ndufu Alike, Ikwo Local Government area of Ebonyi State. The plant leaves were authenticated by a botanist and shade dried for three weeks, and blended into a fine powder using a Q-link electric blender (Model QBL-18L40), and stored in air-tight containers. Five hundred grams $(500 \mathrm{~g})$ was soaked in $1200 \mathrm{ml}$ of water (powder/solvent), and agitated using an electric blender (to enhance proper mixing of the solvent with the powder), and then poured into air-tight plastic container. The container was kept in the refrigerator at $400^{\circ} \mathrm{C}$ for 8hours, followed by filtration with what man's No 1 filter paper $(24 \mathrm{~cm})$. The filtrate was concentrated using rotary evaporator (Model RE52A, China) to $10 \%$ of its volume at $370^{\circ} \mathrm{C}-400^{\circ} \mathrm{C}$. It was concentrated to complete dryness in water bath, and stored in a refrigerator.

\section{Qualitative and quantitative phytochemical analyses of the extract}

Test for tannins: A mixture of $0.5 \mathrm{~g}$ of the extract and $20 \mathrm{ml}$ of distilled water was boiled in a test tube and filtered using a conical flask and filter paper. Formation of blue black coloration when $0.1 \% \mathrm{FeCl}_{3}$ was added to the filtrate indicated the presence of tannins. The quantity of tannins in the extract was determined following the methods of Van-Burden and Robinson [18].

Test for saponins: A mixture of $2 \mathrm{~g}$ of extract and $20 \mathrm{ml}$ of distilled water was boiled in a water bath and filtered. $10 \mathrm{ml}$ of the filtrate and $5 \mathrm{ml}$ of distilled water was mixed in a test tube and shaken vigorously to obtain a stable persistent froth. Formation of emulsion when 3 drops of olive oil was mixed with the froth indicated the presence of saponins. The quantity of saponin in the extract was determined following the methods of Obdoni and Ochuko [19].

Test for flavonoids: Three drops of $1 \%$ ammonia solution was added to a mixture of $10 \mathrm{ml}$ distilled water and $1 \mathrm{~g}$ of extract in a test tube. A yellow coloration indicated the presence of flavonoid compounds. The quantitative analysis was based on the formation of the flavonoids-aluminium complex which has a maximum absorption at $415 \mathrm{~nm}$, as adopted by Laloo D and Sahu AN [20].

Test for steroids: The appearance of a violet coloration that changed to blue in a mixture of $2 \mathrm{ml}$ of acetic acid, $2 \mathrm{ml}$ methanol, $0.5 \mathrm{~g}$ of the extract and $2 \mathrm{ml} \mathrm{H}_{2} \mathrm{SO}_{4}$ confirmed the presence of steroids. The quantity of steroid in the extract was determined in a mixture containing $1 \mathrm{ml}$ of the extract, sulfuric acid (4N, $2 \mathrm{ml})$ and iron (III) chloride $(0.5 \mathrm{w} / \mathrm{v}, 2 \mathrm{ml})$. Potassium hexacyanoferrate (III) solution $(0.5 \% \mathrm{w} / \mathrm{v}, 0.5 \mathrm{ml})$ was added to the mixture, and it was heated in a water bath at $70^{\circ} \mathrm{C}$ for 30 minutes with occasional shaking and diluted to the mark of $10 \mathrm{ml}$ in a volumetric flask with distilled water. The absorbance was measured at $780 \mathrm{~nm}$ against the reagent blank
Steroid concentration $=$ (Average absorbance $\times$ volume of extract $\times 100) /($ weight of sample $\times 1000)$

Alkaloids: A mixture of $0.2 \mathrm{~g}$ of extract and $2 \% \mathrm{H}_{2} \mathrm{SO}_{4}$ was warmed for two minutes, filtered and three drops of Dragendoff's reagent was added. Formation of orange-red precipitate indicated the presence of alkaloids. The quantity of alkaloid in the extract was determined using the method adopted by Harborne [21].

\section{Experimental animals}

Thirty (30) Wister rats were obtained from the department of animal husbandry Ebonyi State University. They were kept during acclimatization and treatment periods at the animal house of the department of biological sciences, Alex Ekwueme Federal University Ndufu Alike Ikwo. They were maintained under standard laboratory conditions $\left(22-28^{\circ} \mathrm{C}, \quad 60-70 \%\right.$ relative humidity, 12:12 h light/dark cycle) with Standard Top Food grower mash and water ad-libitum. The rats were fasted for $24 \mathrm{hrs}$ before commencement of aspirin $(500 \mathrm{mg} / \mathrm{kg}$ body weight) administration.

\section{Experimental procedure}

Thirty wistar rats (about 8 wks old and weight, $120 \mathrm{~g}$ each) were divided into 6 groups of five rats each. With the aid of an oro-gastric cannula, Omeprazole or the extract mixed with $2 \mathrm{ml}$ distil water was administered to the groups as follows: group 1 (negative control) received $2 \mathrm{ml}$ of distil water daily; group 2 received $20 \mathrm{mg} / \mathrm{kg}$ body weight (bwt) of Omeprazole daily for 10 days, followed by $500 \mathrm{mg} / \mathrm{kg}$ bwt of aspirin daily for 3 days; group 3 received $500 \mathrm{mg} / \mathrm{kg}$ bwt of aspirin daily for 3 days, followed by $600 \mathrm{mg} / \mathrm{kg}$ bwt of F.V.E daily for 10 days; group 4 received $500 \mathrm{mg} / \mathrm{kg}$ bwt of aspirin daily for 3 days, followed by $20 \mathrm{mg} / \mathrm{kg}$ bwt of Omeprazole daily for 10 days; group 5 received $600 \mathrm{mg} / \mathrm{kg}$ bwt of F.V.E daily for 10 days, followed by $500 \mathrm{mg} / \mathrm{kg}$ bwt of aspirin daily for 3 days; group 6 (positive control) received $500 \mathrm{mg} / \mathrm{kg}$ bwt of aspirin daily for 3 days. The rats were sacrificed by cervical dislocation and their stomachs were excised and carefully opened along the line of the greater curvature to expose the mucosa.

The stomach was rinsed and fixed in 10\% neutral buffered formalin ( $\mathrm{pH}$ 7.0), dehydrated in ethyl alcohol, then cleared in xylol and embedded in paraffin; 4-6 microns thickness sections obtained and stained with heamatoxylin, eosin and periodic acid Schiff for microscopic examination. The count of cells lining fundic glands and measurement of their diameters were done using CAS 200 image analyzer computer system. The diameters of surface cell and parietal cells were measured; 10 cells per section were observed at X 40 objective by two independent observers. The cell diameter was measured as the average of two diagonal diameters. The count of the cells was done at 40x objective in 10x none overlapping fields for each section. 


\section{Biochemical analysis}

Determination of NP-SH: When the rats were sacrificed, the glandular stomachs were opened and rinsed in ice-cold saline. The tissues were homogenized in TCA solution. The homogenates were centrifuged in ice-cold, and separated into supernatants and pellets. A mixture of the supernatants and 5, 5'-dithiobis (2-nitrobenzoic acid), in phosphate buffer saline containing EDTA ( $\mathrm{pH}$ 7.4) was incubated. Absorption at 412 $\mathrm{nm}$ was read 5 min after it was incubated using Model 6305 (Jenway, USA) spectrometer with a range of 198-1000nm.

\section{Statistical analysis}

Analysis of data was done using computer statistical package for social sciences version 20.0. The level of homogeneity among the groups was tested using analysis of variance (Snedecor and Cochran). Where heterogeneity occurred, the groups were separated using Duncan multiple range test (DMRT). A value of $\mathrm{p}<0.05$ or $\mathrm{p}<0.01$ indicated a significant difference between groups.

\section{Results}

The results are discussed in the following figures and tables in detail (Figures 1-8 and Tables 1-3).

\section{Phytochemical analysis}

Table 1 shows concentrations of the basic phytochemicals in aqueous extract of Ficus vogelii.

Table 1. Concentrations of the basic phytochemicals in aqueous extract of Ficus vogelii leaf found at Ebonyi State, Nigeria.

\begin{tabular}{lcc}
\hline Parameters & Qualitative & Quantity $(\mathbf{m g} / \mathbf{1 0 0} \mathbf{~ m l})$ \\
\hline Saponin & +++ & 3.63 \\
\hline Tannins & + & 0.82 \\
\hline Alkaloids & + & 0.89 \\
\hline Flavonoids & +++ & 3.32 \\
\hline Steroids & ++ & 2.3 \\
\hline+ (Minute), ++ (Less abundant), +++ (Much abundant)
\end{tabular}

\section{Biochemical results}

Table 2 shows effects of aqueous extract of Ficus vogelii leaf and Omeprazole on non-protein sulfhydryl groups (NP-SH) of Wistar rats treated with Aspirin.

\section{Histology results}

Table 3 shows effects of aqueous extract of Ficus vogelii leaf or Omeprazole on gastric surface and parietal cells of wistar rats treated with Aspirin.

\section{Discussion}

Aspirin is used for both therapeutics (to reduce pain, inflammation and fever) and prophylactics (to prevent thrombotic events). Although prophylactic doses of aspirin are generally lower than therapeutic doses, epidemiologic studies suggest that such doses may still be associated with gastrointestinal damage [22]. The dose chosen in this study was similar to the dose chosen by other researchers [23,24], which induced gastric ulceration while used in treatment of osteoarthritis. The pharmacological dynamics and kinetics of Omeprazole has been extensively discussed in the literature. On the other hand, the dosage of FVE used in this study was in the range of values adopted by [4]. That had anti-inflammatory effects in rats. The upper part of the fundic region of the stomach was chosen because it is the most common region for gastric ulcers [25].

Table 2. Effects of aqueous extract of Ficus vogelii leaf and Omeprazole on non-protein sulfhydryl groups (NP-SH) of Wistar rats treated with Aspirin.

\begin{tabular}{ll}
\hline Treatment groups & NP-SH (nmol/g) \\
\hline 1 & $1682.57 \pm 27.94$ \\
\hline 2 & $1473.57 \pm 102.16^{\mathrm{b}}$ \\
\hline 3 & $989.46 \pm 12.81^{\mathrm{a}}$ \\
\hline 4 & $1466.71 \pm 49.35^{\mathrm{b}}$ \\
\hline 5 & $1385.76 \pm 63.99^{\mathrm{b}}$ \\
\hline 6 & $896.42 \pm 6.66^{* *}$ \\
\hline $\begin{array}{l}\text { ** Represents a significant reduction (p<0.01) when compared with negative } \\
\text { control (Group 1). a, bRepresent a significant increase ( }(p<0.05) \text { and }(p<0.01) \\
\text { respectively, when compared with the positive control (Group 6). Values are } \\
\text { means } \pm \text { SD. } n=5 \text { in each group. }\end{array}$ \\
\hline
\end{tabular}

Aspirin administration was accompanied by different forms of gastric mucosal lesions together with collagen fibre deposition in the lamina propria of rats in group $2 \& 6$ (Figures 2 and 6). The findings in group 2 revealed that pre-treatment with Omeprazole could not protect the gastric mucosa from damage induced by aspirin. However, its parietal cell count and that of other test groups, with exception of positive control group could not show a significant difference with the negative control group.

In addition, it revealed a relatively larger surface cell diameter and parietal cell diameter when compared with the positive control group (Table 2). This remarkable structural change of the parietal cells and maintenance of its count within the normal range could be as a result of the fact that Omeprazole has short half-life (0.5-1 hour), slow onset and long-acting pharmacodynamic effect of acid secretion reduction at baseline over 3-5 days.

In support of this result, [26,27] stated that erosion may develop as an ischemic infarct following a therapeutic dose of aspirin. Since, the first structural change in rats is the damage of basement membrane of the endothelial cells of the capillary 
and post capillary venule. It leads to breakdown of small blood vessels before any other cytolysis. Aspirin administration led to increased fibrin deposition in the gastric mucosa [28].
Authors [29-31] detected variable lesions in the gastric mucosal cells following treatment with therapeutic doses of aspirin.

Table 3. Effects of aqueous extract of Ficus vogelii leaf or Omeprazole on gastric surface and parietal cells of wistar rats treated with Aspirin.

\begin{tabular}{|c|c|c|c|c|}
\hline Treatment groups & Surface cell count & Surface cell diameter & Parietal cell count & Parietal cell diameter \\
\hline 1 & $22.26 \pm 2.47$ & $13.52 \pm 0.51$ & $11.81 \pm 0.29$ & $20.85 \pm 0.81$ \\
\hline 2 & $17.52 \pm 1.22^{a}$ & $11.05 \pm 0.83^{a}$ & $12.37 \pm 0.16^{b}$ & $19.04 \pm 0.51^{b}$ \\
\hline 3 & $14.82 \pm 2.67^{a}$ & $10.44 \pm 0.45^{\mathrm{a}}$ & $12.52 \pm 1.47^{\mathrm{b}}$ & $20.41 \pm 0.71^{b}$ \\
\hline 4 & $19.63 \pm 0.65^{\mathrm{b}}$ & $12.46 \pm 0.45^{\mathrm{a}}$ & $14.20 \pm 1.03^{b}$ & $18.58 \pm 0.36^{b}$ \\
\hline 5 & $18.15 \pm 1.76^{b}$ & $12.94 \pm 0.67^{a}$ & $13.03 \pm 0.98^{b}$ & $19.10 \pm 0.62^{b}$ \\
\hline 6 & $12.30 \pm 1.51^{* *}$ & $8.67 \pm 0.94^{*}$ & $18.39 \pm 0.82^{* *}$ & $14.59 \pm 0.54^{* *}$ \\
\hline
\end{tabular}

${ }^{* * * *}$ Represent significant increase or reduction $(p<0.05)$ and $(p<0.01)$ respectively when compared with the negative control $(G r o u p 1)$. a,bepresent significant increase or reduction $(p<0.05)$ and $(p<0.01)$ respectively when compared with the positive control (Group 6$)$. Values are means \pm SD. $n=5$ in each group.

Photomicrographs showing the effects of aqueous extract of Ficus vogelii leaf or Omeprazole on gastric mucosa of wistar rats treated with Aspirin as shown in Figures 1-8.

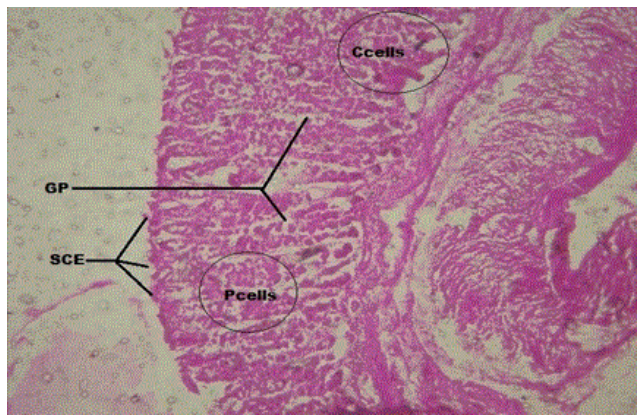

Figure 1. Photomicrograph of a cross-section of the stomach of a rat in group 1 (negative control), showing strong PAS positive reaction with normal Surface columnar Epithelium (SCE), parietal cells and chief cells (PCells and Ccells) and Gastric pits (GP). Stain: PAS; Magnification: 200x.

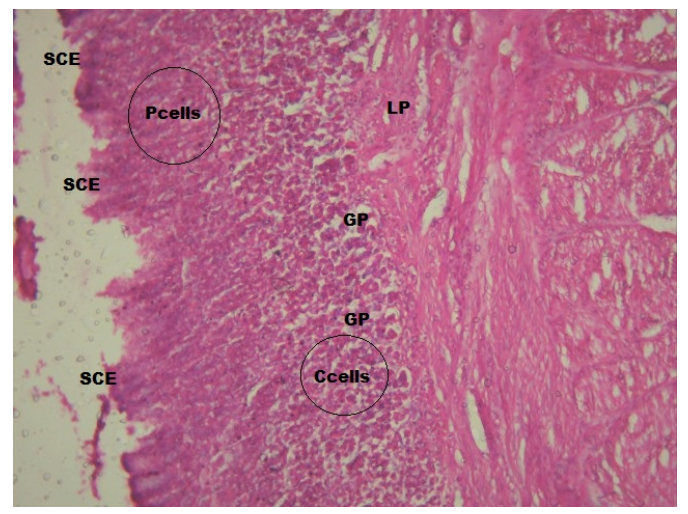

Figure 2. Photomicrograph of a cross-section of the stomach of a rat in group 2, showing degeneration of surface columnar epithelium (SCE), increase in number of parietal and chief cells (PCells and Ccells) and increased fibrin deposition in lamina propria (LP). Stain: H\&E; Magnification: 200x.

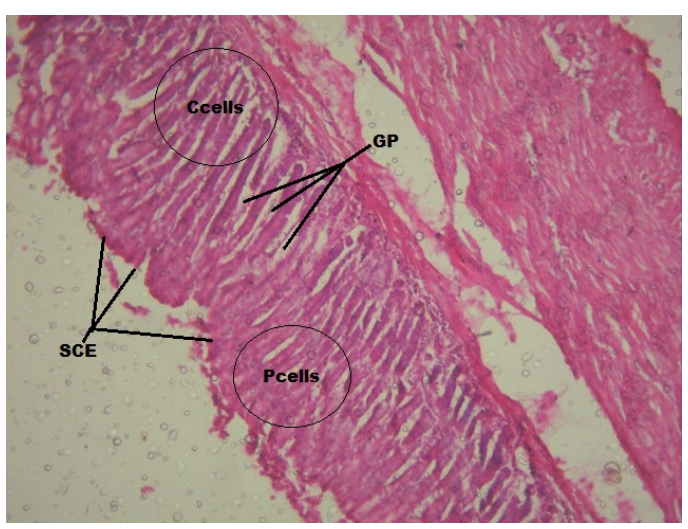

Figure 3. Photomicrograph of a cross-section of the stomach of a rat in group 3, showing normal or lesion regenerated area on surface columnar epithelium (SCE) and Gastric pits (GP), normal count of parietal and chief cells (PCells and Ccells). Stain: H\&E; Magnification: 200x.

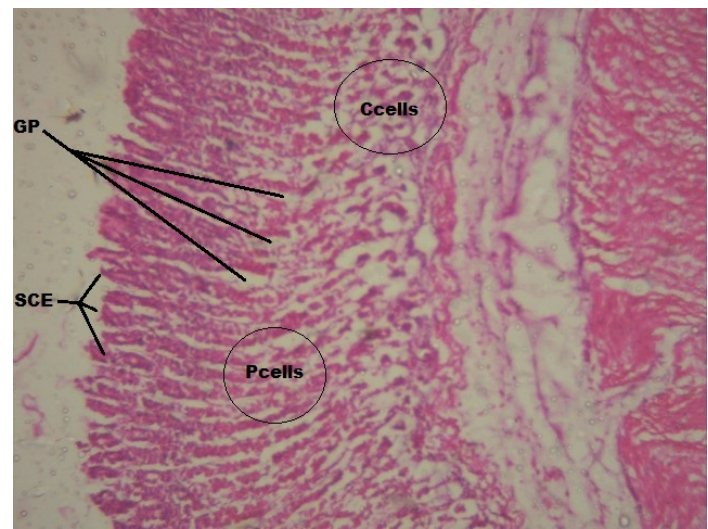

Figure 4. Photomicrograph of a cross-section of the stomach of a rat in group 4, showing normal surface columnar epithelium (SCE), parietal and chief cells (PCells and Ccells), and Gastric pits (GP). Stain: H\&E; Magnification: 200x. 


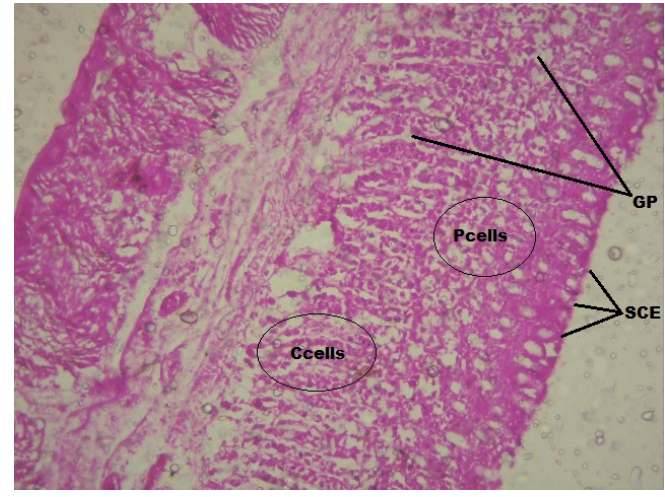

Figure 5. Photomicrograph of a cross-section of the stomach of a rat in group 4, showing strong PAS positive reaction with normal surface columnar epithelium (SCE), normal count of parietal cells and chief cells (PCells and Ccells) and gastric pits (GP). Stain: PAS; Magnification: 200x.

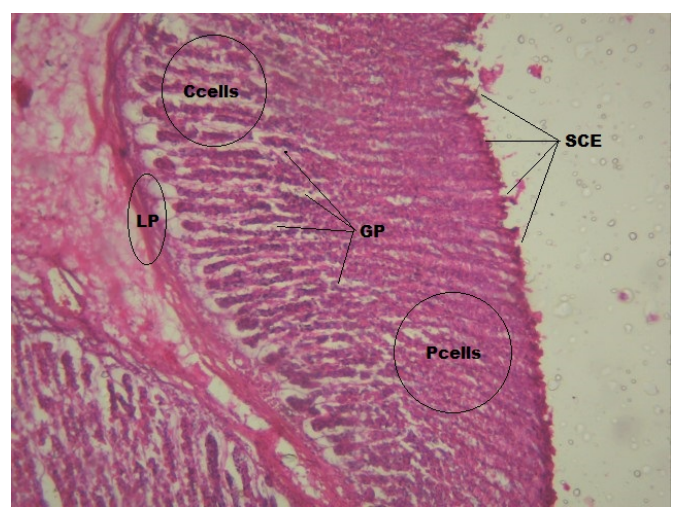

Figure 6. Photomicrograph of a cross-section of the stomach of a rat in group 5, showing normal surface columnar epithelium (SCE), parietal and chief cells (PCells and Ccells) and gastric pits (GP). Stain: H\&E; Magnification: 200x.

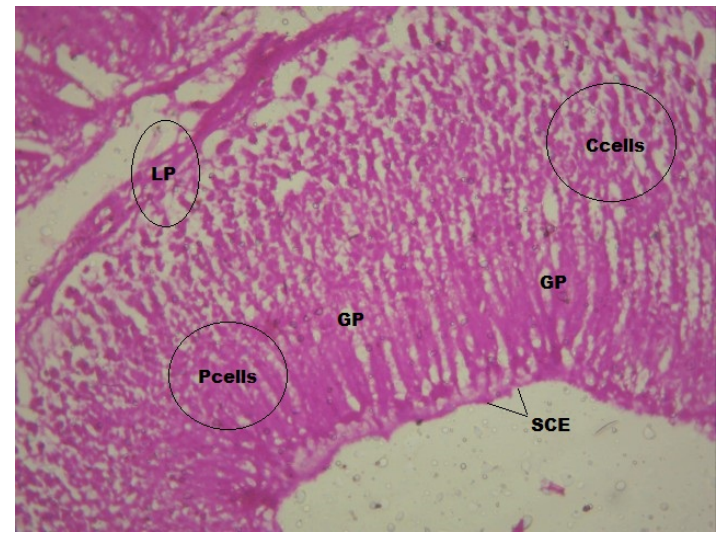

Figure 7. Photomicrograph of a cross-section of the stomach of a rat in group 5, showing strong PAS positive reaction with normal surface columnar epithelium (SCE), parietal cells and chief cells (PCells and Ccells) and gastric pits (GP). Stain: PAS; Magnification: 200x.

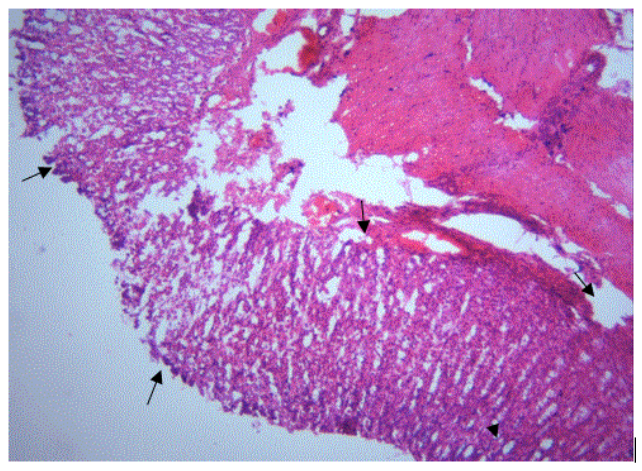

Figure 8. Photomicrograph of a cross-section of the stomach of a rat in group 6, showing (black arrows) gastric ulceration, degenerated surface columnar epithelium, increase in the number of parietal and chief cells, fibrin deposition and bleeding in lamina propria and dilated gastric pits, Stain: PAS; Magnification: 200x.

The result (Table 2) showed that there was no significant change in the concentration of non-protein sulphhydryl group among the treatment groups, with the exception of group 6 (positive control) which showed a significant reduction in its concentration. The endogenous non-protein sulfhydryl groups present in the mucus and some enzymes of the antioxidant system participate in the production of gastric mucus and bind to the free radicals formed during inflammation [32,33] revealed that exposure of gastric mucosa to toxic concentrations of chemicals caused a rapid loss of total protein sulphurhydryl group. Therefore, FVE could have protected the gastric mucosa of Wister rats treated with aspirin by maintenance of normal concentration of non-protein sulphhydryl group.

Interestingly, light microscopic findings on the slides stained with PAS and $\mathrm{H} \& \mathrm{E}$ showed normal structure of surface epithelial cells, lamina propria, parietal and chief cells in negative control group (Figure 1), group 5 (Figures 6 and 7) and group 4 (Figures 4 and 5) with concentrated pink coloration of the mucus on the photomicrographs. Moreover, the therapeutic effect of concomitant administration of aspirin and FVE to rats in group 3 (Figure 3) revealed a normal or lesion regenerated area on surface columnar epithelium. PAS staining technique was adopted since it is mainly used to identify mucus cells, connective tissue and basal lamina.

Noteworthy, this result was in agreement with [24,34]. AspirinFVE induces less gastric mucosal damage due to the increase in expression and activity of hemeoxygenase-1 (HO-1) 45 [35]. HO-1 plays an important role in gastro-protection against NSAID by making cells more resistant to apoptotic death [36,37]. Probably, the above actions of FVE were potentiated by its moderate concentration of steroid, which ultimately could contribute to steroidal anti-inflammatory response [38].

The result of phytochemical analysis showed a relatively, high concentration of saponins and flavonoids in FVE (Table 1). Plant-originated flavonoids are highly gastro-protective. Probably, due to enhancement of the expression of nitric oxide synthase and release of calcitonin gene related peptide by 
sensory afferent nerves that increases gastric microcirculation. Equally noted that some flavonoids were able to simultaneously inhibit the production of inflammatory prostaglandin E2 and pro-inflammatory cytokines $[39,40]$.

Similarly, tomato saponin, alpha-tomatine could potentiate apoptosis and eliminate cells that are abnormal and potentially dangerous [40]. Most likely, FVE saponins might have protected the gastric mucosa of Wister rats in group 3 (Figure 3 ) and 5 (Figures 6 and 7). Through destruction of proliferated parietal and chief cells associated with aspirin administration, with consequent reduction in acid secretion and pepsinogen. This suggestion was supported by the significant increase in number of parietal cells of Wister rats in group 6 when compared with that of negative control group. Thus, the mechanisms of actions of FVE flavonoids and saponins require lucid explanations.

\section{Conclusions}

- Ficus vogelii leaf found at Ebonyi state, Nigeria has abundant flavonoids and saponins, and their mechanisms of actions require lucid explanations.

- $\quad$ FVE could have protected the gastric mucosa of Wister rats treated with aspirin by maintenance of normal concentration of non-protein sulpha-hydryl group that contributes to mucus production and could bind to free radicals formed during inflammation.

- $\quad$ The study proved that F.V.E could be used as both therapy and prophylaxis for aspirin-induced gastric ulcer in Wistar rat while Omeprazole adequately served as a therapy for the ulcer.

\section{Recommendation}

Concomitant administration of aspirin and FVE to prevent and manage aspirin induced gastric ulcer in Wister rat should be subject to randomized clinical trials to ascertain the efficacy.

\section{References}

1. Allen A, Flemstrom G, Garner A, Kivilaakso E. Gastroduodenal mucosal protection. Physiol Revolut 1996; 73: 823-857.

2. Dhikav V, Singh S, Panda S, Atul C, Kuljeet SA. Nonsteroidal Drug-induced Gastrointestinal Toxicity mechanisms and management. JIACM 2003; 4: 315-322.

3. Wang GZ, Huang GP, Yin GL, Zhou G, Guo CJ, Xie CG, Jia BB and Wang JF. Aspirin can elicit the recurrence of gastric ulcer induced with acetic acid in rats. Cell Physiol Biochem 2007; 20: 205-212.

4. Igile GO, Utin IC, Iwara IA, Mgbeje BIA, Ebong PE. Ethanoic extract of Ficus vogelii Ameliorates Dyslipdemia in Diabetic Albino Wister Rats. Int J Curr Res Biosci and plant Biol 2015; 2: 87-96.

5. Bamikole MA, Ikhatua UJ, Arigbede OM, Babayemi OJ, Etela I. An evaluation of the acceptability as forage of some nutritive and anti-nutritive components and of the dry matter degradation profiles of five species of Ficus. Trop Anim Health Prod 2004; 36:157-167.

6. Borelli F, Izzo AA. The plant Kingdom as source of Antiulcer Remedies. Phytotherapy Residence 2000; 14: 581-591.

7. Panda V, Sonkamble M. Anti-ulcer activity of Ipomoea batatas tubers (sweet potato). J Funct Foods Health Dis 2012; 2: 48-61.

8. Abdulla MA, Ahmed KAA, Bayaty FH, Masood Y. Gastro protective effect of Phyllanthus niruri leaf extract against ethanol-induced gastric mucosal injury in rats. Afr J Pharm Pharmacol 2010; 4: 226-230.

9. Naveen J, Jyothi Y, Somashekhar M. Anti-ulcer activity of Aleo vera gel and its interaction with conventionally used antiulcer drug pantoprazole in rat. Am J Pharm Tech Res 2013; 3: 290-97.

10. Akhtar, Ahmad P, Tan CH, Tan BKH. Effects of Averroea bilimbi leaf extract on blood glucose and lipid in STZdiabetic rats. J Ethanopharmacol 2000; 72: 69-76.

11. Akhtar AH, Ahmed KU. Anti-ulcerogenic evaluation of the methanoic extract of some indigenous medicinal plants of Pakistan in Aspirin-ulcerated Rats. J Ethnopharmacol 1995; $46: 1-6$.

12. Akah PA. Purgative potentials of Euphorbia heterophylla. Phytotherapy 1989; 60: 45-48.

13. Singh P, Dutta SR, Guha D. Gastric mucosal protection by Aegle mermolos against gastric mucosal damage: Role of enterochromaffin cell and serotonin. Saudi Gastroenterol 2015; 21: 35-42.

14. Dangarembizi R, Erlwanger KH, Chivandi E. Effect of Ficus thonningii extract on the gastrointestinal tract and clinical Biochemistry of suckling rats. Afr $\mathrm{J}$ Trad complement medicine 2014; 11: 285-291.

15. Awang DV. Quality control and good manufacturing practices: Safety and efficacy of commercial herbs. Food Drug Law 1997; 52: 341-34.

16. Fong HHS. Integration of herbal medicine into modern practices: Issues and prospects. Integr Cancer Ther 2002; 1: $287-93$.

17. Brinker F. Managing and interpreting the complexities of botanical research. Herbal Gram 2009; 82: 42-49.

18. Burden VT, Robinson W. Formation of complexes between protein and Tannin acid. J Agric Food Chem 1981; 1: 77.

19. Obdoni B, Ochuko P. Phytochemical studies and comparative efficacy of the crude extracts of some homostatic plants in Edo and Delta States of Nigeria. Global J Pure Appl Sci 2001; 8: 203-208.

20. Laloo D, Sahu AN. Antioxidant activities of three Indian commercially available Nagakesar. An in vivo study. JChemPharm 2011; 3: 277-283.

21. Harborne JB. Phytochemical methods: A guide to modern techniques of plant analysis. Chapman A and Hall 1973; 279.

22. Hardman JG, Limbird LE Gilman AG. Goodman and Gilman's the pharmacological basis of therapeutics. J Med Chem 2002; 45: 1392-1393. 
wistar rat.

23. Kato S, Suzuki K, Ukawa H, Komoike Y, Takeuchi K. Low gastric toxicity of nitric oxide-releasing aspirin, NCX-4016, in rats with cirrhosis and arthritis. Dig Dis Sci 2001; 46: 1690-1699.

24. Konturek PC, Kania J, Gessner U, Konturek SJ, Hahn EG, Konturek JW. Effect of vitamin C-releasing acetylsalicylic acid on gastric mucosal damage before and after Helicobacter pylori eradication therapy. Eur J Pharmacol 2004; 506: 169-177.

25. Augustin MO, Medina SF, Medina JrSF. Effect of psychogenic stress on gastrointestinal function. J Physiol Biochem 2000; 56: 259-274.

26. Lee M. Age-related changes in gastric blood flow in rats. Gastroenterol 1996; 42: 289 - 293.

27. Brzozowski T, Kwiecien S, Konturek PC, Konturek SJ, Musiol M, Duda A, Bielanski W, Hahn EG. Comparison of nitric oxide-releasing NSAID and vitamin $\mathrm{C}$ with classic NSAID in healing of chronic gastric ulcers; involvement of reactive oxygen species. Med Sci Monit 2001; 7: 592-599.

28. Banerjee A, Peters TJ, James PB, Perrins DD, Schofield PF, Haboubi NY, Schved JF, Gris JC, Dubois A, Raffanel A, Martinez PAT. Pathogenesis of Crohn's disease. Lancet 2 1989; 334: 1459-1460.

29. Shea DT, Steel L, Montcalm ME, Dubois A. Aspirininduced changes in gastric function: Role of endogenous prostaglandins and mucosal damage. Gastroenterology 1990; 98: 284-292.

30. Caselli M, Corte LR, Carlo DL, Aleotti A, Trevisani L, Ruina M, Trotta F, Alvisi V. Histological findings in gastric mucosa in patients treated with non-steroidal antiinflammatory drugs. J Clin Pathol 1995; 48: 553-555.

31. Kanter M, Demir H, Karakaya C, Ozbek H. Gastro protective activity of Nigella sativa $\mathrm{L}$ oil and its constituent, thymoquinone against acute alcohol-induced gastric mucosal injury in rats. World J. Gastroenterol 2005; 11: 6662-6666.

32. Avila JR, Lastra CA, Martin MJ, Moltiva V, Luque I, Delgado D, Esteban J, Herrerias J. Role of endogenous sulphhydryl and neutrophil infiltration in the parthenogenesis of gastric mucosal injury induced by Piroxicam in rats. Inflamm 1996; 45: 83-88.
33. Nagy L, Nagata M, Szabo S. Protein and nom-protein sulfhydryl and disulfides in gastric mucosa and liver after gastro toxic chemicals and sucralfate: Possible new targets of pharmacologic agents. World J Gastroenterol 2007; 13: 2053-2060.

34. Konturek PC, Kania J, Hahn EG, Konturek JW. Ascorbic acid attenuates aspirin induced gastric damage: Role of inducible nitric oxide synthase. J Physiol Pharmacol 2006; 57: 125-136.

35. Aburaya M, Tanaka KI, Hoshino T, Tsutsumi S, Suzuki K, Makise M, Akagi R, Mizushima. Heme oxygenase-1 protects gastric mucosal cells against non-steroidal antiinflammatory drugs. J Biol Chem 2006; 281: 33422-33432.

36. Sabiston DC, Townsend CM, Beauchamp RD, Evers BM, Mattox KL. Sabiston textbook of surgery: The biological basis of modern surgical practice. Saunders/Elsevier 2008.

37. Wallace JL, Tigley AW. New insights into prostaglandins and mucosal defense. Aliment Pharmacol Ther 1995; 9: 227-235.

38. Zayachkivska OS, Konturek SJ, Drozdowicz D, Konturek PC, Brzozowski T, Ghegotsky MR. Gastroprotective Effect of Flavonoids in Plant Extracts. J Physio Pharmacol 2005; 56: 219-231.

39. Ribeiro D, Freitas M, Tome SM, Silva AM, Laufer S, Lima JL, Fernandes E. Flavonoids inhibit Cox-1 and Cox-2 enzymes and cytokine/chemokine production in human whole blood. Inflammation 2015; 38: 858-870.

40. Kudelova J, Seifrtova M, Sucha L, Tomsik P, Havelek R, Rezacova M. Alpha-tomatine activates cell cycle checkpoints in the absence of DNA damage in human leukemic MOLT-4 cells. J Appl Biomed 2013; 11: 93-103.

\section{*Correspondence to}

Ezemagu U Kenneth

Department of Anatomy

Faculty of Basic Medical Sciences

Alex Ekwueme Federal University

Nigeria 